\title{
Status of Work Values of Elementary School Teachers in Congressional District I, Division of Nueva Ecija
}

\author{
Bernardo A. Zabala Jr, ${\text { Ph } \mathbf{D}^{2 *} \text {, Helene Grace M. Lachica }}^{1}$ \\ ${ }^{1}$ Associate Professor 2, Head, Extension Services/ Guidance Counsellor, Graduate School/College of Nursing \\ Graduate School, Nueva Ecija University of Science and Technology, Cabanatuan City, Nueva Ecija, \\ Philippines \\ ${ }^{2}$ Teacher, Bardias Elementary School, Licab District, Department of Education, Nueva Ecija
}

*Corresponding Author: Bernardo A. Zabala Jr, Teacher, Bardias Elementary School, Licab District, Department of Education, Nueva Ecija

\begin{abstract}
This study entitled "Status of Work Values of Elementary School Teachers in Congressional District I, Division of Nueva Ecija" sought to answer 1) how may the socio-demographic profile of the teacher respondents be described in terms of gender, age, civil status, educational attainment and length of service? 2) How may the teachers' work values be described as they rated themselves and by their principals? 3) Is there a significant relationship between socio-demographic profile of the teachers and their status of work values? Does the status of work values of teachers significantly differ across schools as they rated themselves and by their principals? What are the problems encountered by the teachers and principals relative to the work performance and their suggested solutions? Data were gathered through questionnaire distributed to nine (9) school heads, and ninety seven (97) teachers and in nine (9) central schools in Congressional District I, Nueva Ecija. Descriptive statistics frequency count, percentage distribution, and the mean weighted average, Fishers' Exact Test, Spearman Correlation, Kruskal Wallis Test were utilized as statistical tools to interpret data. The results imply that the nine principals observed that the status of work values of the teachers in central school of CD I in the Division of Nueva Ecija was very high.
\end{abstract}

Keywords: Work values, significant, Descriptive, Kruskal Wallis Test

\section{INTRODUCTION}

When teachers join the school system, they bring with them traits and attributes that may affect the performance of their role either favorably or unfavorably. Teachers need to carry out effectively whatever responsibilities and tasks assigned to them. The work values which teachers bring into their workplace determine their needs which are either physiological or psychological. Likewise, teachers' performances are strongly founded on the job values they adhere to. [1]

In addition to being knowledgeable about the subjects they teach, teachers must have the ability to communicate, improve trust and confidence and motivate students, as well as understand the students' educational and emotional needs. Teachers must be able to recognize and respond to individual and cultural differences of students and employ different teaching methods that will result in higher student achievement. They should be organized, dependable, patient and creative. [2] Teachers must also work cooperatively and communicate effectively with other teachers, support staff and parents and other member of the community. These are some work related values of teachers.

Experiences of successful teachers have shown that the teacher's job is not concerned solely in the transmission of knowledge and information. The task of a teacher is complex and many-sided and demands a variety of work related values and competencies.

The work values of teachers spell achievement or disappointment. Higher work values promote morale and greatly contribute for continued good performance. Willingness to perform and enthusiasm to do their job are manifestations of favorable work values. [3]

The administrators that recognize the work values of teachers will boost their enthusiasm to work and produce more. Principals and other school heads must provide opportunities that promote wholesome 

Ecija

working conditions and desirable working environment as these contribute to the satisfaction of the teachers' work values.

Recognizing the work related values of teachers should also be a priority in any school organization. The role of teachers can be best appreciated when their behavior toward job are considered. The work values that teachers hold when properly harnessed by principals, supervisors, and higher authorities can enhance satisfaction and productivity. Work values upheld by teachers make them perform their job either willingly and enthusiastically or poorly and reluctantly. [4]

To know what makes a good teacher, one must know their work related values, hence this study was conducted.

\section{OBJECTIVES OF THE STUDY}

This study attempted to investigate and analyze the status of work values among elementary school teachers in Congressional District I, Division of Nueva Ecija. It delved on their socio-demographic profile in terms of: gender; age; civil status; educational attainment; and length of service. The teachers' work values as they rated themselves and by their principals? Is there a significant relationship between socio-demographic profile of the teachers and their status of work values? Does the status of work values of teachers significantly differ across schools as they rated themselves and by their principals? What are the problems encountered by the teachers and principals relative to the work performance and their suggested solutions?

\section{THEORETICAL AND CONCEPTUAL FRAMEWORK}

The behavioral management theory (Maslow, 1954) was used in this study. It is often called the human relations movement because it addresses the human dimension of work. [5]

He developed one of the most widely recognized need theories, a theory of motivation based upon a consideration of human needs. Maslow's hierarchy of needs helped managers visualize employee motivation. Based on more general human needs and motivations, the different work values were categorized as extrinsic or security/material values (e.g. Pay, security, work environment); social or relational values (e.g. interacting with people, altruism, contribution to society); status or power values (e.g. prestige, authority, influence).

Using this theorem as reference, this study came up with the conceptual framework in which the teachers' work values were described, compared and contrasted. There were factors to consider in evaluating the status of work values of teachers. With such work values, administrators and teachers should consider factors in initiating how to address the problem related to them and apply proper action. In order to create quality action, status of work values must be determined. [6]

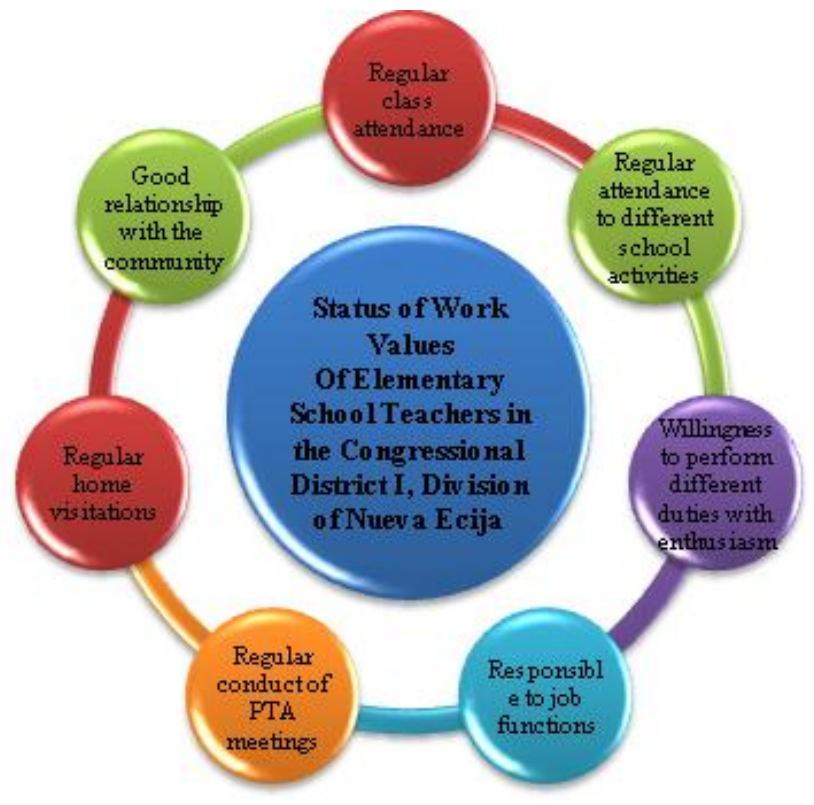

Figure1. The Conceptual Paradigm showing the relationship between the independent and dependent variables 

Ecija

The areas evaluated under teachers' socio-demographic profile were gender, age, civil status, educational attainment and length of service. For the work values of teachers, categories considered the regular attendance in class and in different school activities, willingness to perform different duties, responsible to job functions, regular conduct of PTA meetings, regular home visitations and establishing good relationship with the community as independent variables of the study. The overall rating of teachers and principals on the formers' work values constituted the status of work values of teachers classified as very high, high, average, below average and poor. [7]

It was conceptualized in this study that the socio-demographic profile of the teachers and their work values as they rated themselves and by their principals were correlated with their status of their work values and also the similarities and difference of the status of work values across the different schools were compared and contrasted.

The conceptual framework (Figure 1) illustrated the relationships that exist between the independent variables and dependent variable.

\section{RESEARCH METHODOLOGY}

This study, the correlational research design using survey method was used since it involved the relationship between profiles and status of work values of teachers in selected elementary schools in the Congressional District I, Division of Nueva Ecija. It also involved the difference in the status of work values among teachers in different schools.

The respondents involved nine (9) principals and ninety seven (97) teachers from the nine central schools in the Congressional District I, Division of Nueva Ecija School Year 2013-2014. Thirty percent $(30 \%)$ of teachers from each central school were drawn through simple random sampling, where all third names that appeared in the list of the teachers taken from the office of the principal office is were considered as sample. On the other hand, complete enumeration was used for the principals.

The research instrument used in gathering data was adopted from the Index Checklist by Gary Blau (1999). Revisions were undertaken to specifically mention the term teaching profession as a career. Respondents were offered five options for an answer: $5=\quad$ Very High - the work values of teacher is inherent and truly manifested without hesitation; 4 = High - the work values of teacher is always manifested; $3=$ Average - the work values of teacher is manifested; $2=$ Below Average the work values of teacher is seldom manifested; $1=$ Poor - the work values of teacher is not manifested at all.

The first part of the instrument used in gathering data focused on determining the profile of teachers such as age, gender, civil status, educational attainment and length of service. The second part of the questionnaire assessed the work values of respondents, the problems encountered relative to work related values and the suggested possible solutions. The questionnaire utilized the five-point Likert scale that measures the ratings of the respondents regarding status of work values in relation to profiles.

The adopted Checklist was subjected to a test-retest in the research locale and administered to teachers who were not used as respondents in the study. The interval of the administration of the checklist was two weeks. The scores during the first test were compared with the scores obtained during the second administration employing Pearson's Moment Correlation as the statistical tool. The obtained reliability index was .078 which manifested dependability and consistency of the instrument.

Prior to the conduct of survey, a letter was made requesting the Schools Division Superintendent, District Supervisor and Principals for permission to administer the questionnaire on the study schools and respondents, the principals, and teachers. Upon approval, the instrument was distributed to the respondents. The groups of respondents were given copies of the instrument intended for them. To make the retrieval easy and speedy, a follow up visit to the study schools was done by the researcher herself.

Responses generated through the questionnaires were tabulated and analyzed using appropriate descriptive statistics and other test criteria to answer the stated specific problems of the study. 

Ecija

To determine the socio-demographic profile and rating of the respondents concerning work values, the researcher utilized descriptive statistical tools such as frequency counts, mean, percentages and standard deviation.

\section{Legend}

$4.20-5.00$

$3.40-4.19$

$2.60-3.39$

$1.80-2.59$

$1.00-1.79$

\section{Mean Verbal description}

Very High

High

Average

below Average

Poor

To determine the significant relationship between the socio-demographic profile of teachers and status of work values, Spearman Correlation and Fishers' Exact Test were utilized. Spearman Correlation is used to assess whether there is relationship between two or more variables. Fishers' Exact Test is a statistical significance test used for small sample sizes.

To determine the significant difference in the status of work values of the teachers across the different schools as rated by the teachers and principals, Kruskal Wallis Test was utilized. Kruskal Wallis Test is most commonly used when there is one nominal variable and one measurement variable, and the measurement variable does not meet the normality assumption of an ANOVA.

\section{RESULTS AND DISCUSSION}

\subsection{Teacher Respondents Socio Demographic Profile}

Socio demographic profiles of the respondents were described to reveal significant information about age, gender, civil status, educational attainment and length of service of the teachers.

\subsubsection{Gender of Teacher-Respondents}

The gender of teacher respondents was classified as male or female. Figure 2 showed the gender of the teachers.

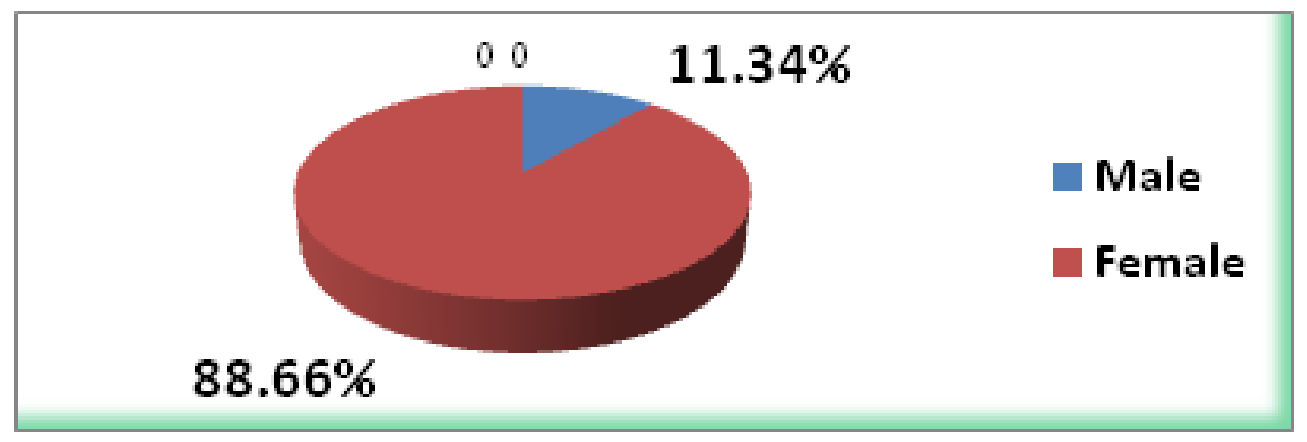

Figure2. Gender of Teacher-Respondents

Findings showed the dominance of female teachers $(88.66 \%)$ in number while only 11.34 percent of the teachers-respondents were male. Since most of the respondents were female, the findings implied that they contribute as bread winner to augment the financial capabilities of their families.

The findings confirmed previous results on sex and education that teaching has always been dominated by women. A study conducted by Dela Rosa (2003) revealed the dominance of female student-teachers in CLSU suggesting that teacher education attracts more female than male. Polintan (2007) found out also that majority of teachers in her study were female.

\subsubsection{Age of Teacher-Respondents}

Figure 3 showed the ages of the teachers. It was ranges from 20-30, 31-40, $41-50$ and above 50 years. Of the 97 teachers respondents, $40(41.24 \%)$ of them were between $31-40$ years old. Thirty three $(34.02 \%)$ teachers belonged to $41-50$ years old age bracket. Twenty one $(21.65 \%)$ of them were above 50 and only $3(3.09 \%)$ were in the $20-30$ years age bracket. 


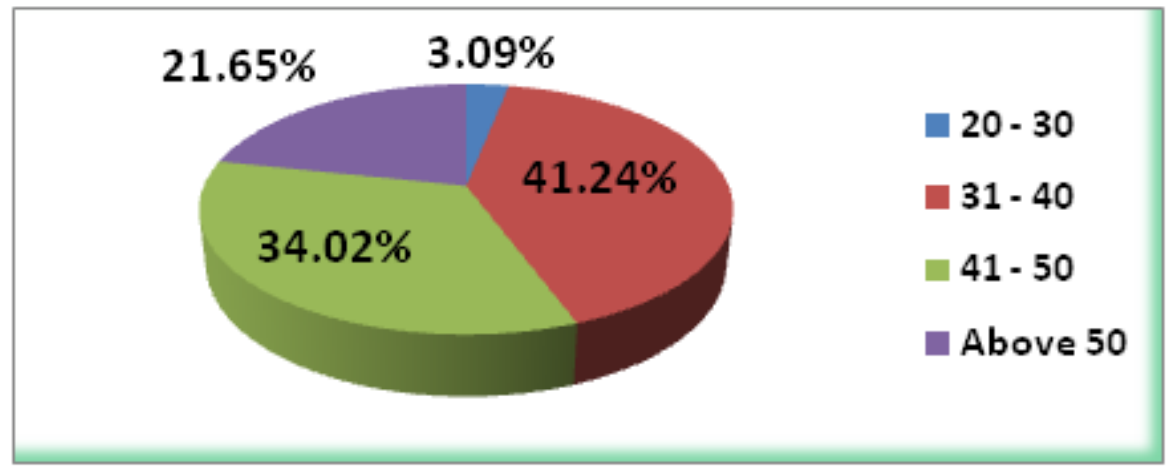

Figure3. Age of Teacher-Respondents

These findings are similar with the study of Gesta (2006) of the 206 teacher respondents, mostly of them were between the ages of 31-40 years old. The age was largely scattered implying that a wide distribution existed in terms of respondents' age.

\subsubsection{Civil Status of Teacher-Respondents}

The civil status of the teachers was presented in Figure 4. It was classified as single, married, separated and widow.

The data on Figure 4 showed that most $(92.79 \%)$ of the respondents were married. This is expected because most of the Filipinos get married after getting a permanent job (Vicmudo 2001). Therefore, it is expected that they have already their own family. Three point nine percent $(3.09 \%)$ of them were still single. There was also three point nine percent $(3.09 \%)$ of the teachers who were widow while $1.03 \%$ was separated as to the time of the study.

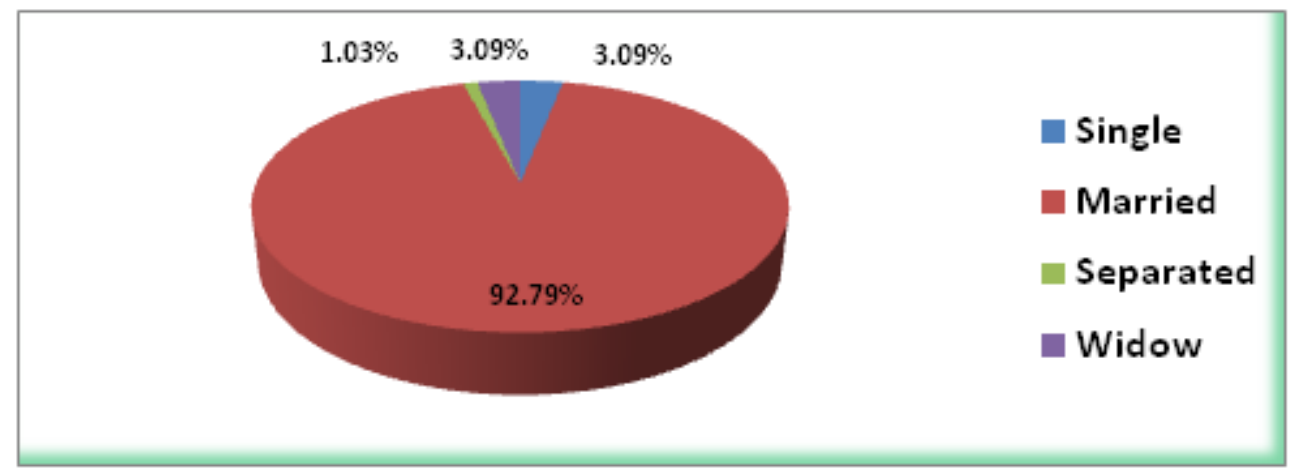

Figure4. Civil Status of Teacher-Respondents

The results were similar to previous studies. Polintan (2007) and Paez (2000) found out that majority of the teachers were married.

\subsubsection{Educational Attainment of Teacher-Respondents}

The teachers were asked to list the highest educational attainment. The results were presented in Figure 5.

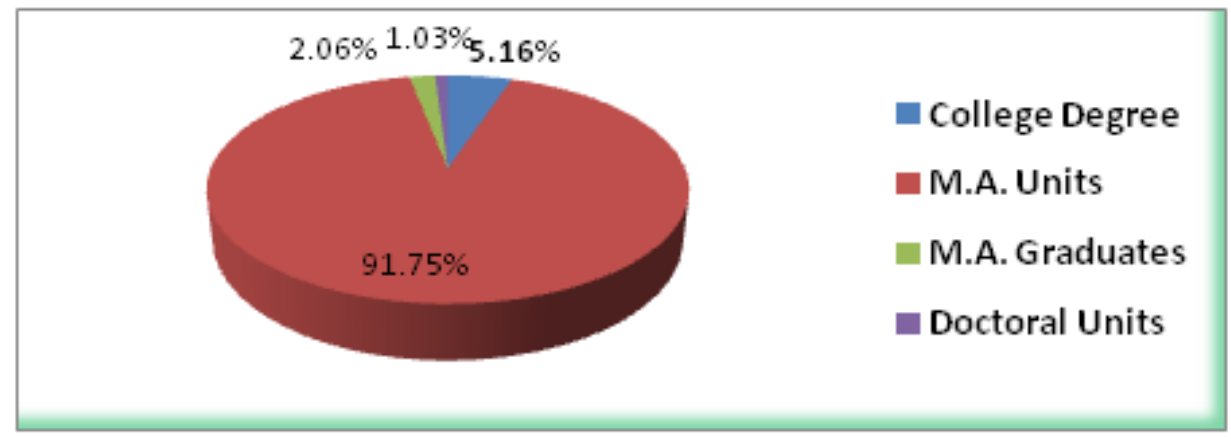

Figure5. Educational Attainment of Teacher-Respondents 

Ecija

As regards to highest educational attainment of teachers, results in Figure 5 showed that most $(91.75 \%)$ were Bachelor's degree graduate with MA/MS units although some of them $(2.06 \%)$ were MA/MS graduate. Five point sixteen percent $(5.16 \%)$ of them still hold College degree and $1.03 \%$ earned doctoral units. These results imply that the respondents tried to pursue professional growth in education so they can be promoted to higher position or rank in teaching.

\subsubsection{Length of Service of Teacher-Respondents}

The last variable for the profile to be discussed in this study is length of service of the teachers.

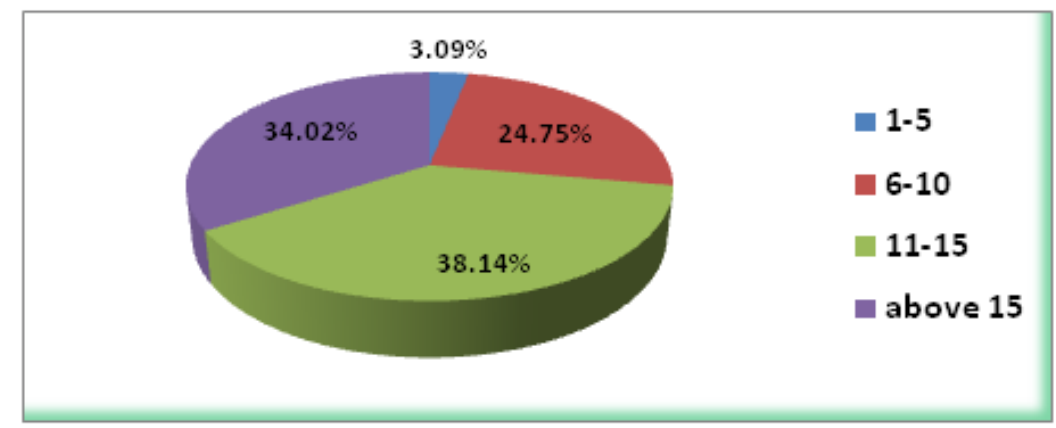

Figure6. Length of Service of Teacher-Respondents

$$
\bar{x}=13.84 \quad S D=5.05 \text { years }
$$

Presented in Figure 6 is the range of number of years in teaching of the teachers, 38.14 percent of the respondents have been teaching for 11-15 years. The least number of the respondents reported themselves having taught from 1-5 years $(3.09 \%)$. Thirty four point two percent $(34.2 \%)$ of the teacher-respondents were teaching for more than fifteen years. Twenty four point seventy five percent of them were teaching for 6-10 years. The mean of 13.84 with a standard deviation of 5.05 years revealed that the teachers have already accumulated substantial pool of knowledge and skills in teaching. Data further show that majority $(38.14 \% ; 34.02 \%)$ of the respondents were employed a decade ago.

Some studies revealed higher results of years of experience. As cited by Polintan (2007) in the Division of Pangasinan and in Zambales that teachers' years of experience was more than 20 years and 18 years, respectively. In the study of Del Mundo (2005) the mean years of experience of the teachers in Nueva Ecija is 18 years. The same result was evident in earlier study of Dela Rosa (2007) where majority of the faculty were engaged in the teaching profession for ten years or more.

\subsection{Work Values of Teachers as Rated by the Teacher Themselves}

The second problem of the study was to know the teacher and principals rating on the work values of the teacher.

The work values of the teachers got an overall mean of 4.41 with a verbal description of very high. It only means that the status of work values of teachers is very high.

The work values of the teachers which were rated very high are attending the class regularly ,willingness to perform different duties with enthusiasm, responsible to his/her job functions, conducting PTA meetings regularly and attending different school activities regularly with a mean of $4.79,4.61,4.60,4.53$ and 4.48 respectively.

Findings of study also showed that the status of teachers' work values such as establishing good relationship with the community and making regular home visitations are high status with a mean of 4.15 and 3.91.

\subsection{Work Values of Teachers as the Principals Rated Them}

The principals' rating about the work values of the teacher is presents in Table 3 . The mean was interpreted as very high, high, average, below average and poor.

All the work values presented to the principals got a very high verbal description with an overall mean of 4.83. or the principals, attendance of teachers in their class regularly got a mean of $(\overline{\mathbf{x}}=4.89)$ attending to different school activities regularly $(\overline{\mathbf{x}}=4.89)$, willingness to perform different duties with enthusiasm ( $(\overline{\mathbf{x}}=4.89)$, responsibly attending to their job functions $(\overline{\mathbf{x}}=4.78)$ conducting PTA meetings 

Ecija

regularly ( $\overline{\mathbf{x}}=4.89)$, making home visitation regularly $(\overline{\mathbf{x}}=4.78)$ and establishing a good relationship with the community ( $\overline{\mathbf{x}}=4.67)$. The results imply that the nine principals observed that the teachers in central school of Congressional District I in Nueva Ecija had a very high status in their work values.

\subsection{Relationship between Socio-Demographic Profiles of Teachers and Status of Work Values}

Another problem in this study was to know if there were significant relationship between sociodemographic profiles of teachers and status of work values. Table 4 presented the significant results using Spearman Correlation and Fishers Exact Tests as statistical tools.

\subsubsection{Gender and Status of Work Values}

Table 4 shows the relationship between gender and teachers' status of work values. Gender was highly significant to status of work values of teachers in terms of establishing good relationship with community (Sig. Value $=0.00$ ). The findings may be accounted to the dominance of female teachers who participated in this study (Figure 2) and in the study of Kaushal and Janjua (2011), it was shown that females have shown higher inclination than their counterparts for the personal work values like autonomy, power and recognition.

Table4. Shows the relationship between gender and teachers' status of work values

\begin{tabular}{|l|l|l|l|l|l|}
\hline WORK VALUES & Gender & Age & Civil Status & $\begin{array}{l}\text { Educational } \\
\text { Attainment }\end{array}$ & $\begin{array}{l}\text { Length of } \\
\text { Service }\end{array}$ \\
\cline { 2 - 6 } & Sig. Value & Sig.Value & Sig. Value & Sig.Value & Sig. Value \\
\hline $\begin{array}{l}\text { 1. The teacher attends his/her } \\
\text { classes regularly. }\end{array}$ & 0.11 & $0.024^{*}$ & 1.00 & $0.001^{* *}$ & 0.602 \\
\hline $\begin{array}{l}\text { 2.The teacher attends different } \\
\text { school activities }\end{array}$ & 0.69 & 0.272 & 1.00 & $0.001^{* *}$ & 0.326 \\
\hline $\begin{array}{l}\text { 3. The teacher is willing to perform } \\
\text { different duties with enthusiasm. }\end{array}$ & 0.11 & $0.003^{* *}$ & 1.00 & $0.002^{* *}$ & 0.927 \\
\hline $\begin{array}{l}\text { 4. The teacher is responsible to } \\
\text { his/her job functions. }\end{array}$ & 0.11 & $0.005^{* *}$ & 1.00 & $0.018^{*}$ & 0.702 \\
\hline $\begin{array}{l}\text { 5. The teacher is conducting PTA } \\
\text { meeting regularly. }\end{array}$ & 1.00 & 0.547 & 0.57 & $0.037^{*}$ & 0.257 \\
\hline $\begin{array}{l}\text { 6. The teacher makes regular home } \\
\text { visitation }\end{array}$ & 0.32 & 0.637 & 1.00 & 0.155 & 0.310 \\
\hline $\begin{array}{l}\text { 7. The teacher establishes a good } \\
\text { relationship with the community. }\end{array}$ & $0.000^{* *}$ & $0.000^{* *}$ & 1.00 & 0.089 & $0.011^{*}$ \\
\hline
\end{tabular}

It can also be noted that the gender has no significant relationship to status of work values of teachers in terms of regular class attendance, attendance to different school activities, willingness to perform different duties with enthusiasm, responsible to job functions, conducting PTA meeting regularly and regular home visitations.

\subsubsection{Age and Status of Work Values}

Age was highly significant to teachers' status of work values in terms of being responsible to job functions (sig.value $=0.005$ ), willingness to perform different duties with enthusiasm (sig.value $=0.003$ ) and establishing good relationship with the community (sig.value $=0.000$ ).

Table 4 also showed that age is significantly related to the status of work values in terms of attending the class regularly (sig.value $=0.024$ )

The results may be accounted to the dominance of teacher-respondents who belong to the matured bracket (Figure 3) and find support from Ho (2006) who found out that age is positively associated with work values, job involvement and organizational commitment Polintan (2007) also claimed that age of the teachers to be significantly related with job functions. Employees with high work values, who had high job-involved attitudes, were most likely to be committed to their organization.

Likewise many think that performance improves with age. Some factors in job performance can be related to age like difference in motivation and attitudes toward work, cognitive functioning, and age discrimination and the structure and environment of the work place (Velasquez, 2010).

On the other hand, age is not significantly related to work values such as attendance to different activities, conduct of PTA meetings and home visitation. 


\subsubsection{Civil Status and Status of Work Values}

The status of work values of teachers in terms of regular class attendance (sig.value $=1.00$ ), attendance to different activities (sig.value=1.00), performance of different duties with enthusiasm (sig.value $=1.00$ ), responsible to job functions (sig.value $=1.00$ ), conduct of PTA meetings (sig. value $=$ 0.57 ), regular home visitation (sig.value $=1.00$ ) and relationship with the community (sig.value $=1.00$ ) has no significant relationship with the civil status of teachers as shown in Table 4.

This runs contrary to the result of the study of Kaushal and Janjua (2011) that performance work values dutifulness, timeliness, teamwork, self efficacy, emotional stability and responsibility have been noticed differing significantly between the married and unmarried groups of respondents.

\subsubsection{Educational Attainment and Status of Work Values}

Table 4 showed the relationship of educational attainment of the teacher and the status of work values.

Educational attainment of teachers has high relationship with regular class attendance. It can be also noted that educational attainment of the teacher is highly significant to the work values such as attendance to different school activities regularly and their willingness to perform different duties. On the other hands, educational attainment of the teachers is significantly related in conducting PTA meetings and in being responsible to job functions.

From the data obtained, educational attainment of the teacher has no relationship to work values of teachers in terms of making home visitations and establishing good relationship with the community.

The findings is in agreement with Kamwendo (2000) who revealed in her study that usually, higher educational qualification means more exposure to new ideas and more creativity which may accelerate productivity and growth. It also provides broader and wider scope of knowledge. The more educated the person is the more confidence and better performance he displays.

In contrary to the findings, Harris \& Sass (2006) confirmed in their research that there were small effects of experience and educational background on teacher performance. In addition, they found that a teacher's college major was unrelated to their classroom performance.

\subsubsection{Length of Service and Status of Work Values}

As shown in table 4, length of service is significantly related to the status of work values in terms of establishing good relationship with the community with a significant value of 0.011 .

The length of service of the teachers is not significantly related to the status of work values of teachers in terms of class attendance, attendance to different activities, performance of different duties with enthusiasm, responsibility to job functions conduct of PTA meeting and home visitation has no significant relationship with the length of service of teachers.

The findings are in agreement with Antolin (2010) who claimed that experience is related to a number of dependent variables, one of which is performance. The length of service has significant effect on the job, leadership, behavior and performance. Furthermore, teacher's performance is not only associated with educational qualifications, but also with length of teaching experience. The longer the experience, the better is the performance and Rabacal (2005) who states that the more experienced the teachers are, the more efficient and competent by become in doing their activities. Also, they are exposed to different measures or solutions applicable to the varying needs and problems of the pupils.

The first hypothesis of the study that states that there is no significant relationship between sociodemographic profiles of teacher and their status of work values is rejected, since there were four variables that had a significant relation to status of work values of teachers, the gender, age, educational attainment and length of service. Moreover for the socio-demographic profile of teachers in terms of civil status that has not shown significant relations to the status of work values of teacher is accepted.

\subsection{Difference in the Status of Work Values across the Different Schools}

The significant difference in the status of work values of teachers across different schools was also aimed to know in this study. Kruskal Wallis Test was utilized as a statistical tool to interpret the data obtained. 

Ecija

Table5. Differences in the Status of Work Values of Teachers among Different Schools

\begin{tabular}{|l|l|l|l|}
\hline Work Values & Chi Square & df & Asymp. Sig. \\
\hline 1. The teacher attends his/her classes regularly. & 10.540 & 8 & 0.229 \\
\hline 2. The teacher attends different school activities & 8.946 & 8 & 0.347 \\
\hline $\begin{array}{l}\text { 3. The teacher is willing to perform different duties with } \\
\text { enthusiasm. }\end{array}$ & 19.459 & 8 & $0.013^{*}$ \\
\hline 4. The teacher is responsible to his/her job functions. & 8.342 & 8 & 0.401 \\
\hline 5. The teacher is conducting PTA meeting regularly. & 18.974 & 8 & $0.015^{*}$ \\
\hline 6. The teacher makes regular home visitation. & 4.402 & 8 & 0.819 \\
\hline 7. The teacher establishes a good relationship with the community. & 6.223 & 8 & 0.622 \\
\hline
\end{tabular}

*significant

Table 5 showed the differences in the status of work values among different schools as rated by the teachers and principals.

There were significant differences in the status of work values of teachers in terms of willingness to perform different duties with enthusiasm and conducting PTA meeting regularly which marked a significant values of 0.013 and 0.015 . It only means that the status of work values of teachers in the different schools differ in terms of willingness to perform different duties with enthusiasm and conducting PTA meeting regularly. The findings may be accounted to some teachers with very high status of work values on willingness to perform different duties with enthusiasm and conducting PTA meeting regularly while the other has only high status.

The result also shows that there were no significant differences in the status of work values of teachers in terms of regular class attendance (sig.value $=0.229$ ), attendance to different activities (sig.value $=0.347$ ), responsible to job functions (sig.value=0.401), regular home visitation (sig.value $=0.819$ ) and good relationship with the community (sig.value $=0.622$ ).

Therefore, the second hypothesis of the study stating that there are no significant differences in the status of work values across different schools as rated by the teachers and principals is rejected because two work values categories were significantly different. The hypothesis is however accepted for the work values which have not shown significant difference.

\subsection{Problems Encountered Relative to Work Performance and the Suggested Solutions}

There were common problems encountered by the teacher and principal relative to the work performance of the teacher. Listed below are the problems they encountered and their suggested solutions.

Table6. Problems Encountered by the Teacher Relative to their Work Performance

\begin{tabular}{|l|l|l|l|}
\hline $\begin{array}{l}\text { Problems Encountered by the } \\
\text { Teacher in Performance of their } \\
\text { Work }\end{array}$ & $\mathbf{f}$ & $\%$ & Suggested Solutions \\
\hline Behavior of pupils & 83 & 85.57 & $\begin{array}{l}>\text { Parents should start disciplining their children at } \\
\text { home } \\
\text { There must be strict supervision/guidance of parents } \\
\text { to the children } \\
\text { Inform the parents about the performance and } \\
\text { behavior of pupils by conducting PTA meetings } \\
\text { regularly }\end{array}$ \\
\hline $\begin{array}{l}\text { Low parental and family } \\
\text { engagement at the school program }\end{array}$ & 78 & 80.41 & $\begin{array}{l}>\text { Parents should involved more themselves in school } \\
\text { programs and support their children in their studies. }\end{array}$ \\
\hline $\begin{array}{l}\text { Too much school and paper works } \\
\text { and having no time for the family }\end{array}$ & 61 & 62.89 & $\begin{array}{l}>\text { Proper scheduling of works/tasks } \\
>\text { Time management. }\end{array}$ \\
\hline
\end{tabular}

Table 6 shows the problems encountered by the teacher in terms of the performance of their work. One of the problems encountered by the teachers was the behavior of the pupils $(85.57 \%)$. The suggested solution they listed were parents should start disciplining their children at home, there must be strict supervision/guidance of parents on their children, and inform the parents about the performance and behavior of pupils by conducting PTA meetings regularly. 

Ecija

Another problem they encountered was the parents' factor. It means there is low parental and family engagement in the school program $(80.41 \%)$. The teachers suggested that parents should involve themselves more in school program and support their children in their studies. Parents should also give proper attention to their children's needs.

Sixty two point eighty nine percent $(62.89 \%)$ of the teacher claimed that there is too much school and paper works that lessen the quality of their outputs and lack of quality time for their family. The suggested solution to this is proper scheduling of school tasks and time management.

\subsection{Problems Encountered by the Principal Relative to the Work Performance of the Teacher}

Problems are usual and almost inevitable accompaniment of man's daily grind (Directo, 2005). Table 7 presents the problems encountered by the principal in terms of the work performance of their teachers.

Table7. Problems Encountered by the Principal Relative to the Work Performance of the Teacher

\begin{tabular}{|l|l|l|l|}
\hline $\begin{array}{l}\text { Problems Encountered by the } \\
\text { Principal in Performance of Work } \\
\text { of the Teacher }\end{array}$ & $\mathbf{f}$ & $\%$ & Suggested Solutions \\
\hline $\begin{array}{l}\text { Teachers are not eager to attend } \\
\text { seminars }\end{array}$ & 6 & 66.67 & $\begin{array}{l}\text { Give the teachers incentives like recommending them } \\
\text { for outstanding teacher or increase their CB-PAST }\end{array}$ \\
\hline "I don't care" attitude & 5 & 55.56 & Conduct values formation seminar for the teachers \\
\hline $\begin{array}{l}\text { Parents are just relying on their } \\
\text { children about what is happening } \\
\text { inside the school. }\end{array}$ & 5 & 55.56 & Parents should aware of the school policies. \\
\hline
\end{tabular}

On the side of the principals, the common problems they encountered in terms of performance of the work of their teacher were teachers are not eager to attend seminars (66.67\%); they rather like to stay in their classroom and teach. The Suggested solutions for this is give the teachers incentives like recommending them as outstanding teacher or increase the rating in their CB-PAST. Fifty five point fifty six percent (55.56\%) of the principal said that some teachers also have an "I don't care" attitude. Principals suggest that there should be values formation seminar for the teachers. Another problem is that parents just rely on their children about what is happening inside the school $(55.56 \%)$. The solution suggested was parents should engage more about the school policies.

In the study of Velasquez (2010), it was found out that most of the faculty had problems related to stress and fatigue, lack of seminars and trainings, gossip, tardiness and lack of opportunity for professional advancement and work load.

\section{CONCLUSION}

The following conclusions were derived from the findings.

1. The teachers respondents were mostly female, 31-50 years, female, married, college graduate with Masteral units and teaching for 11 to 15 above years.

2. The work values of the teachers were very high. The nine principals observed that the teachers in central school of Congressional District I in Nueva Ecija were very high in terms of the status their work values

3. A significant relationship between socio-demographic profile of teacher and status of work values in terms of the gender, age, educational attainment and length of service. There was no significant relationship between the civil status of teachers and status of work values.

4. A significant difference exists in the status of work values among different schools as rated by the teachers and principals in terms of performance of different duties and conducting PTA meeting regularly.

5. The problems encountered by the teachers relative to the work performance were the behavior of the pupils, parents' factor and too much paper works. The possible solutions they gave were parents support to their children and time management. For the principal, the problems they encountered were attitude of the teacher and parents' factor. The suggested solutions were giving the teachers incentives and parents' involvement in school policies.

\section{RECOMMENDATIONS}

Based from the findings and conclusions, the following recommendations were offered: 
1. The teacher should continue to pursue higher level of education for their professional growth and to enhance the status of their work values.

2. Higher school authorities should ceaselessly endeavor to provide the teachers avenues and opportunities where their high work values are maintained and sustained. They should also closely monitor the status of work values to find out if this affects the effective delivery of services for the attainment of goals and objectives.

3. Teacher must involve themselves to participate in school programs and activities as this will intensify their enthusiasm in performance of roles and duties.

4. Teachers and principals must continue to seek possible solutions to the problems encountered relative to the work of the teacher and apply it for better performance of their work.

5. The study can be replicated in other research locale and use the neutral gender as respondents and include religion and ethnicity as independent variable.

\section{LiTERATURE Cited}

[1] AARONSON, D., BARROW, L., SANDER, W., 2007. Teachers and Student Achievement in the Chicago Public High Schools, Journal of Labor Economics, 25(1), 95-135January 23, 2018

[2] AVAN, B. I. RAHBAR, M.H. AND RAZA, S.A. (2007) The Role of Family Configuration in Early Childhood Intellectual Development System in Pakistan. Journal for Postgraduate Medicine. Retrieved on January 23, 2018

[3] CARTECIANO, JOWI A. 2009. National research council of the Philippines. Retrieved on November 20, 2017 from http://nrcp.dost.gov.ph/

[4] PAEZ, C. P. 2000 Job Milieu Relationship to the Role Disposition and Work Perspective of department Heads in the National Public Secondary Schools. Unpublished Dissertation, Araullo University, Cabanatuan City, Nueva Ecija. Retrieved on January 18, 2018

[5] MASLOW'S HIERARCHY OF NEEDS Retrieved on February 1, 2018 from http://businesscasestudies. co.uk/business-theory/people/human-needs-and-rewards.html\#ixzz2sxt0syVt

[6] PICART, A. A. 2003. Assessment of the Capabilities of Aurora State College of Technology (ASCOT) Towards Meeting Human Resource Needs of Aurora Province. Dissertation, Central Luzon State University, Science City of Muñoz, Nueva Ecija. Retrieved on January 18, 2018

[7] POLINTAN, P. P. 2007. Leadership Role of Principals in Public Secondary Schools in District II, Division of Nueva Ecija. Unpublished MS thesis, Central Luzon State University, Science City of Muñoz, Nueva Ecija. Retrieved on January 18, 2018

\section{OTHER REFERENCES}

[1] CASAYURAN, MARIO B. (2010). Provide textbooks first, Angara proposes. Retrieved on September 20, 2017

[2] CELEP, C. E. 2009. Teachers Organizational Commitment in Educational Organization. Retrieved on November 24, 2017 from http://128.3.20.41/ep//papers/0309/098888.pdf

[3] CRUZ, J. S. 2007. Involvement of the CLSU secondary school faculty in instruction, research and extension services: Implication to educational management. Unpublished MS Thesis, Central Luzon State University, Science City of Muñoz, Nueva Ecija, Retrieved on January 3, 2018

[4] DELA ROSA, E. D. 2003. Program Analysis of Student Teaching of the Central Luzon State University. Unpublished MS thesis, Central Luzon State University, Science City of Muñoz, Nueva Ecija., Retrieved on January 3, 2018

[5] DEL MUNDO, J. F. 2005. Role Performance of Public Central School Administrators in selected School of district 2, Nueva Ecija. Unpublished MS thesis, Central Luzon State University, Science City of Muñoz, Nueva Ecija., Retrieved on January 23, 2018

[6] DIRECTO, R. 2005. Academic and Personal Attributes as Determinant of Faculty Performance in Selected Universities of Region III. Dissertation, Central Luzon State University, Science City of Muñoz, Nueva Ecija., Retrieved on January 23, 2018

[7] GANIBAN, SHIELla MARIE A. 2012. Selected Teacher Factors And Their Relation To Students' Performance In The Regional Achievement Test (Rat) In Chemistry In The Division Of Nueva Ecija. Central Luzon State University., Retrieved on January 23, 2018

[8] GESTA, P. I. 2006. Instructional Leadership Behavior of School Principals in National High Schools of Nueva Ecija. Unpublished MS thesis, Central Luzon State University, Science City of Muñoz, Nueva Ecija., Retrieved on January 23, 2018 
[9] HOC.C. 2006. A stusy of Relationship between Work values, Job Involvement and organizational commitment among Taiwanese Nurses Retrieved on January 23, 2018

[10] JACOBA, F. P. (2008) The Emotional quotient and teaching performance of selected faculty of the Nueva Ecija University of Science and Technology. NEUST Graduate School Research Journal, Vol.5, pp.9-22 Retrieved on January 23, 2018

[11] KAMWENDO, E. A. 2000 Factors Influencing Faculty Performance in Selected Private Universities of Region III. Dissertation, Central Luzon State University, Science City of Muñoz, Nueva Ecija. Retrieved on January 20, 2018

[12] KAUSHAL S. L. AND JANJUA Y. S. 2011 An Empirical Study on Relationship between Personal Work Values and Performance Work Values Retrieved on October, 2017 from http://113.3.220.41/ep//papers/ 0309/098888.pdf

[13] KINGDON, G.G. 2006. Teacher characteristics and student Performance in India: A pupil fixed effects approach. Retrieved on January 29, 2018 from http://www.gprg.org/pubs/workingpapers/pdfs/gprg-wps059.pdf

[14] KIYOKAWA Y. AND YAMAWE H. (2004) Japanese Labor View, Journal of Ohara Institute of Social Studies. Retrieved on January 23, 2018

[15] LAITONG P. 2002. Selected Factors Influencing the Instructional Performance in Vocational Education Institutions in Chumpon Province, Tailand. Unpublished MS thesis, Central Luzon State University, Science City of Muñoz, Nueva Ecija. Retrieved on January 23, 2018

[16] MANGULABNAN, B. T. 2007. School performance in the 2005 NAT (Elementary): Implication to educational management. Unpublished MS thesis, Central Luzon State University, Science City of Muñoz, Nueva Ecija. Retrieved on January 19, 2018

[17] RABACAL, M.P. 2005.Assessment of teacher performance in the University of Santo Tomas grade school using the revised faculty evaluation tool. Unpublished MS thesis, Central Luzon State University, Science City of Muñoz, Nueva Ecija. Retrieved on January 17, 2018

[18] RAMOS, C.V.C 2002. Predicting Teaching Performance of Mathematics Teacher in Region III. Unpublished MS thesis, Central Luzon State University, Science City of Muñoz, Nueva Ecija, Retrieved on January 17, 2018

[19] REMO, I. G. (2001). Faculty Empowerment In State Colleges and Universities. The Modern Teacher: Vol.XLIX, No. 10. Manila: Grade School Inc. Philippine Council for Print Media, Retrieved on January 20, 2018

[20] ROBBINS, S.P. 2005. Organizational Behavior Pearson Education South PTE. Phil. Edition, Retrieved on January 19, 2018

[21] ROCKOFF, J. E. 2003. The impact of individual teachers on student Achievement: evidence from panel data. Retrieved on January 19, 2018 from http://129.3.20.41/eps/pe/papers/0304/030400.pdf

[22] SIU, O.L. 2003. Job Stress and Job Performance among Employees in Hongkong: The Role of Chinese Work Values. International Journal of Psychology, Retrieved on January 25, 2018

[23] TANAKA, N. 2011 The Cross- Cultural Study of Work Values: Focus on Religion, Leisure Time and School Education, Retrieved on January 23, 2018

[24] The Philippine Journal of Education. 2006. Volume LXXXIV, Number 10, March 2006, Retrieved on January 25, 2018

[25] VELASQUEZ, J. V. 2010 Work Motivation, Job Satisfaction, Work Needs and Problems of Faculty: Basis for a Proposed Faculty Development Program for State Universities in Region III. Unpublished Dissertation, Nueva Ecija University of Science and Technology, Cabanatuan City, Nueva Ecija., Retrieved on January 24, 2018

[26] WORANCHA G. 2000. Parent and Teacher Influence on values Acquired by Senior Education Students in the Universities of Nueva Ecija-Philippines. Dissertation, Central Luzon State University, Science City of Muñoz, Nueva Ecija, Retrieved on January 23, 2018

Citation: Bernardo A. Zabala Jr, et.al,. "Status of Work Values of Elementary School Teachers in Congressional District I, Division of Nueva Ecija" International Journal of Research in Sociology and Anthropology (IJRSA), vol 4, no. 2, 2018, pp. 40-51. doi:http://dx.doi.org/10.20431/2454-8677.0402005.

Copyright: (C) 2018 Authors. This is an open-access article distributed under the terms of the Creative Commons Attribution License, which permits unrestricted use, distribution, and reproduction in any medium, provided the original author and source are credited. 